\title{
ТЕОРЕТИЧНИЙ КОНТЕКСТ ФОРМУВАННЯ МОРАЛЬНОЇ КУЛЬТУРИ МАЙБУТНЬОГО ВЧИТЕЛЯ ПОЧАТКОВИХ КЛАСІВ ЗАСОБАМИ ІНФОРМАЦЙНО-КОМУНІКАЦІЙНИХ ТЕХНОЛОГІЙ
}

\author{
KATERYNA LATYSHEVSKA, Postgraduate studies Lviv
} State University of Life Safety, Ukraine

\section{ТЕОРЕТИЧНИЙ КОНТЕКСТ ФОРМУВАННЯ МОРАЛЬНОЇ КУЛЬТУРИ МАЙБУТНЬОГО ВЧИТЕЛЯ ПОЧАТКОВИХ КЛАСІВ ЗАСОБАМИ ІНФОРМАЦІЙНО-КОМУНІКАЦІЙНИХ ТЕХНОЛОГІЙ}

\begin{abstract}
У статті аналізуються питання сутності і змісту поняття моральна культура, здійснюється теоретичний аналіз процесу формування моральної культури в майбутнього вчителя початкових класів засобами інформаційно-комунікаційних технологій. "Моральна культура" як інтегральне поняття віддзеркалює світоглядні, моральні і культурні почуття, переконання, ідеали, норми і принципи людської поведінки, діяльності, а також реальний рівень людських взаємин. Обгрунтовується ідея холістичного підходу у становленні майбутнього вчителя початкових класів, що розглядається як важлива методологічна основа його цілісності, набутті гуманістичного світогляду, переконань і вчинків. Акцентується увага на тому, що застосування інформаційно-комунікаційних технологій у формуванні моральної культури майбутнього вчителя початкових класів має практично необмежені можливості. Водночас їх використання повинно бути професійним, компетентним і системним.

Ключові слова: особистість, учитель початкової школи, студент, моральна культура вчителя, інформаційно-комунікаційні технології, дитино-, людиноцентризм
\end{abstract}

The article analyzes the nature and content of the concept of "moral

(с) К. Латишевська culture", provides a theoretical analysis of the process of formation of moral culture in a future teacher of primary classes by means of information and communication technologies. "Moral culture" as an integral concept reflects the worldview, moral and cultural feelings, beliefs, ideals, norms and principles of human behavior, activity, as well as the real level of human relationships. The idea of a holistic approach to the formation of a future primary school teacher was substantiated, which was considered as an important methodological basis for its integrity, acquisition of a humanistic worldview, beliefs and actions. The article draws attention to the fact that the use of information and communication technologies in the process of shaping of the moral culture of a future teacher has virtually unlimited possibilities. At the same time, it emphasizes their professional, competent and systematic application.

Key words: personality, elementary school teacher, student, teacher's moral culture, information and communication technologies, child-human centrism

Мета: здійснити теоретичний аналіз формування моральної культури майбутнього вчителя початкових класів засобами IКТ та визначити основні напрями подальших наукових досліджень в означеному контексті.
Постановка проблеми в загальному вигляді. Підготовка майбутнього вчителя початкових класів здійснюється на двох основних рівнях - професійному та особистісному. Професійний рівень передбачає набуття студентом ще у стінах закладу вищої освіти відповідних компетентностей (переважно технологічно-функціонального характеpy), які дозволили б йому в майбутній практичній діяльності ефективно використовувати закони і закономірності, принципи, форми i методи, засоби та сучасні технології навчання, передусім інформаційно-комунікаційні (ІКТ). Ця підготовка вимагає також набуття майбутнім педагогом належної методологічної культури, уміння здійснювати експериментальні дослідження тощо.

Не менш важливою складовою становлення майбутнього вчителя початкових класів $\epsilon$ рівень його особистісної підготовки, зокрема. це стосується сформованості високого рівня моральної культури. Цей аспект проблеми актуалізується не лише необхідністю здійснення теоретичних пошуків, а й нагальними потребами духовного розвитку як учня, так і вчителя. Сьогодні, попри всі намагання утвердити ідеї людино- та дитиноцентризму, надто очевидною видається ситуація антикультури, моральної деградації, розбещеності не лише молоді (агресивність, у формі хамства, булізму, пиятики, наркозалежності 
тощо), а і старшого покоління, що приносить величезні збитки як суспільству, так і самій особистості. Сформована 3 допомогою інформаційно-комунікаційних технологій моральна культура майбутнього вчителя початкових класів значною мірою сприятиме розв'язанню цієї складної педагогічної проблеми.

Аналіз досліджень і публікацій. До наукових праць, які безпосередньо присвячені питанням моральної культури і формування іiї у майбутніх вчителів засобами IКТ, відносимо такі: Т. Бешок, Г. Васянович, А. Кондратюк, С. Кубрак та інші.

Прикметно, що такі пошуки здійснюються як на традиційних, так й інноваційних засадах. Очевидно, що сучасна педагогіка все більше віддаляється від традиційних принципів, форм, методів і засобів впливу на особистість; вона динамічно набуває нового змісту, функціональності, застосування новітніх інформаційно-комунікаційних технологій. Змінюються iï теоретикометодологічні й концептуальні засади щодо обгрунтування вдосконалення системи освіти в Україні, підготовки учителів різного фаху, у тому числі й вчителів початкових класів.

Виклад основного матеріалу дослідження. Значна кількість вітчизняних та зарубіжних учених (В. Андрущенко, І. Бех, С. Гончаренко, I. Зязюн, Д. Петко, Г. Філіпчук, Б. Хонеггер, I. Шемпрух та ін.) доводить, що навчально-виховний процес має будуватися на холістичних началах. Це означає, що особистість майбутнього вчителя початкових класів повинна розглядатися не одномірно, а багатовимірно, у всій сукупності його якостей, властивостей, культурних надбань тощо. Нам імпонує ця думка, вона є слушною і вартісною, водночас зауважимо, що в ній немає абсолютного заперечення так званого "знаннєвого" підходу, оскільки знання були і залишаться важливим змістовим елементом продуктивної підготовки вчителя, формування його моральної культури. Натомість і тут відбувається сутнісна зміна парадигм: якщо англійський філософ, учений XV-XVI ст. Ф. Бекон наголошував, що "знання - сила", то сьогодні спрацьовує нова парадигма: "пізнання - сила". Академік I. Бех. глибоко досліджуючи процеси, що відбуваються в сучасній психології і педагогіці, акцентує, що сьогодні варто реалізувати провідний принцип: "Знання і пізнання - гуманістично орієнтована сила", яка базується передусім на людино- й дитиноцентризмі, отже, на пізнанні і самопізнанні цілісної людини. Учений доводить, що теперішньому суспільству потрібна педагогіка духовно значущої дії особистості (Бех, 2006, с. 19-20). Очевидно, що мова йде про одну з основних установок гуманітарної парадигми: ціннісно-смислову рівність учителя й учня, тобто як рівноправних суб'єктів навчально-виховного процесу. 3 іншого боку, гуманітарна парадигма передбачає застосування нового гносеологічного підходу в підготовці майбутнього вчителя, формування його моральної культури засобами інформаційно-комунікаційних технологій. Цей аспект спрямовує особистість майбутнього вчителя на глибоке усвідомлення того, що процес пізнання і самопізнання $є$ неперервним та нескінченним. Набуття знань у цій площині не є самоціллю, а імперативом постійного саморозвитку, самовиховання такої важливої складової, якою виступає моральна культура. Лише за дотримання даної умови майбутній учитель початкових класів буде здатним якісно здійснювати свою професійну діяльність.

Підготовка студента, формування його моральної культури у своєму змістовому аспекті має враховувати не лише набуття суто професійних знань, а й особистісних, до яких, передусім, відносимо знання 3 проблем загальнолюдської і вітчизняної культури, мистецтва, етики й естетики тощо. На переконливу думку I. Огієнка, моральна культура - це інтегративне поняття, яке віддзеркалює світоглядні, моральні і культурні почуття, норми і принципи людських взаємин (Огієнко, 1992).

На наше переконання, варто звернути увагу і на такий аспект проблеми: застосування інформаційно-комунікаційних технологій 3 їх практично необмеженими можливостями в набутті різноманітних знань майбутнім педагогом, безумовно, мають великий позитив (індивідуалізація та диференціація навчання; підвищення рівня активності; сприяння вияву мотивації навчання; покращення умов для самостійної роботи студентів тощо). Натомість очевидним є те, що у цьому процесі криється і значний негатив, який часто-густо перешкоджає міцному засвоєнню знань. Логіка студента тут, зазвичай, така: навіщо засвоювати знання, запам'ятовувати їх, якщо в будь-який час можна звернутися до комп'ютера і знайти необхідну інформацію. Помилка даного судження очевидна. По-перше, справжнє знання це не просто інформація, яку можна легко відтворити за певних умов, знання - це стимул до моральної, культурної дії. Вони мають бути збереженими в певній системі. Вільне володіння набутими знаннями 3 різних галузей науки отримують статус функціональності, отже, суб'єктивної цінності. Студент має добре усвідомити предметно-практичне значення знань для своєї професійної діяльності, уміти послідовно самостійно поповнювати їх, збагачуватися ними.

Науковці акцентують і на проблемному характері знань, тобто традиційний підхід у цьому питанні змінюється на нелінійний (синергетичний), що у свою чергу, спрямовує свідомість майбутнього вчителя на виявлення суперечностей, які постійно супроводжують процес виникнення нових знань та їх опанування. Традиційний підхід до недавнього часу базувався на раціоналістичному принципі, згідно 3 яким знання і пізнання істини досягається лише на основі розуму. Нині ситуація значно змінилася, і саме тому все більше науковці (а не лише представники богослов'я) дотримуються тієї думки, що існують знання найвищої сутності, які неможливо сприйняти й усвідомити одним лише розумом. Способом їх пізнання вважається духовний досвід. Як доводять Г. Васянович та В. Онищенко, "...адекватно виявити сутність духовності особистості можна на засадах християнськофілософської ноології - філософії духа і духовного пізнання" (Васянович \& Онищенко, 2012, с. 3). Для нашого дослідження цей підхід $\epsilon$ продуктивним тому, що відкриває значні можливості в пізнанні такого феномена, яким бачимо моральну культуру майбутнього вчителя початкових класів.

Формування моральної культури вчителя початкових класів відбувається за умови, коли знання ста- 
ють фундаментом умінь і навичок. Як слушно зауважив академік В. Кремень: "... в історії перемагає та спільнота (народ, плем'я, нація), яка добре засвоїла справу накопичення, вдосконалення, розповсюдження і передачі відповідних знань, навичок і вмінь" (Кремень, 2008, с. 6). У цьому контексті вважаємо за потрібне наголосити на тій позиції, згідно з якою свідоме, творче використання знань сприяе активному формуванню вмінь, надає їм форми гнучкості, позбавляє стереотипності тощо. Отже, знання у цьому випадку є не самоціллю, а ефективним засобом досягнення педагогічної мети в контексті формування моральної культури вчителя початкових класів. На такий аспект проблеми звертає увагу В. Каплінський. Учений не лише глибоко дослідив співвідношення цих понять, проаналізував рівні знань і вмінь, а і з'ясовував, за яких саме умов знання стають фундаментом умінь (Кремень, 2008, с. 15-16).

Крім того, аналіз окресленої проблеми спонукає до думки, що за сьогоднішніх умов розвитку суспільства майбутній учитель початкових класів повинен набувати грунтовних знань, умінь і навичок, пов'язаних із соціалізацією дітей, що значною мірою підсилює його моральну культуру. Висловлена ідея знайшла достатнє обгрунтування у науковому дослідженні О. Будник. Учена доводить, що підготовка майбутнього вчителя повинна здійснюватися $з$ урахуванням належного педагогічного супроводу соціалізації молодших школярів як механізму й результату соціальнопедагогічної діяльності. "Соціально-культурна реальність, - пише О. Будник, - здійснює істотний вплив на теорію і практику соціального виховання, зокрема, визначення технологічних засад використання соціально-педагогічного потенціалу суспільства для успішної соціалізації особистості в сучасному мінливому соціумі. Таким потенціалом є суспільна практика народу, його особливості світогляду, етикет поведінки, духовність і мораль" (Будник, 2014, с. 117).

Важливу роль у цьому процесі відіграють сформовані навички, які забезпечують у цілому стереотипну автоматизовану дію, що протікає у подібних ситуаціях, умовах. Тому можна говорити про те, що підго- тувати майбутнього вчителя початкових класів до вищого рівня професійної діяльності, його моральної культури - це означає, що ще у процесі навчання в закладі освіти він має набути відповідних до його обов'язків, знань, умінь і навичок.

Особливо це стосується навичок з використання інформаційнокомунікаційних технологій. Здійснений Т. Бешок аналіз навчальних планів та програм низки педагогічних ЗВО засвідчив, що в цій ланці $\epsilon$ значні проблеми. Так, на перших курсах усіх педагогічних спеціальностей ТНПУ імені В. Гнатюка викладається курс "Сучасні інформаційні технології", який включає 1,5 кредити, однак, із загальної кількості годин (80) на аудиторні заняття виділено лише 12 лекційних і 24 години лабораторних. Велика кількість матеріалу пропонується студентам для самостійного опрацювання, який вони ще не в стані добре опрацювати, оскільки їм бракує демонстрації послідовності виконання вправ та наочного викладання (Бешок, 2014, с. 54).

Висловлене дає підстави потвердити, що "знаннєвий" (точніше 3У-Нівський) підхід щодо формування моральної культури майбутнього вчителя початкових класів повністю себе ще не вичерпав. Натомість, як було зазначено вище, сьогодні він уже не може бути пріоритетним, провідним, оскільки соціально-економічні, політичні, культурно-освітні процеси різко змінюються, виникають нові явища, яких раніше не було і які потребують глибокого, усебічного осмислення. Головним у такому процесі $\epsilon$ те, що за умов глобалізації, відкритого суспільства змінилася сама людина, змінився вчитель і учні, їх світогляд, морально-культурний світ, духовні цінності тощо. Саме тому пріоритету набувають холістичні ідеї, які спрямовують пошук науковців до знаходження найбільш оптимальних можливостей формування моральної культури фахівця будь-якого профілю, у тому числі й учителя початкових класів.

Нам імпонує слушна думка академіка С. Гончаренка, котрий доводив, що оптимальним шляхом у вирішенні проблеми підготовки вчителя в моральному, культурному сенсі є дотримання принципу фундаменталізації педагогічної освіти. "Фундаменталізація освіти, - писав учений, - передбачає істотні зміни в традиційних технологіях навчання. Сьогодні навчальний матеріал пропонується учням і студентам в логіці опису, домінує чисто предметна, інформаційна, а не методологічна освіта, елементний, а не якісний підхід до навчання. Натомість майбутній спеціаліст має бути методологом, який відзначається широтою і глибиною наукових поглядів і культурою мислення, як дисциплінарного, так і міждисциплінарного, системного. У педагогіці вищої освіти існує такий феномен, як "розірваність мислення". Студент знає суть окремих понять, теорій, законів, може їх відтворити, але лише на "логіці опису". В умовах домінуючого у вищій школі інформаційно-репродуктивного навчання у студента виробляється лінійне мислення, стереотипне, причинно-наслідкове. Тому він оволодіває не "наукою й професією, а ремеслом" (Гончаренко, 2008, с. 87-88).

Упровадження принципу фундаменталізації освіти ще більш посилює роль і значення ІКТ у підготовці вчителя початкових класів, формуванні його моральної культури. Головним тут виступає стратегія професійного використання IKT. Ïї науково обгрунтував академік Р. Гуревич: "Ураховуючи дані психологічних досліджень, можна констатувати, що ефективне освоєння потенціалу засобів ІКТ потребує відповідної підготовки вчителя, який повинен дотримуватися певних умов..." (Гуревич, 2008, с. 92). Дослідник акцентує на тому, що досконале застосування IКТ у підготовці вчителя, формування професійних якостей змінює не лише його власну моральну культуру, а й усього навчального закладу.

Холістичний підхід стосовно підготовки вчителя початкових класів, його моральної культури дотримується позиції формування у нього наукового світогляду. А науковий світогляд - це новий, більш високий рівень моральності і культури. Видатний учений України В. Вернадський називав його ноосферним. Він писав: "Науковий світогляд є створенням і виявом людського духа.... науковий світогляд змінюється в різні епохи у різних народів, має свої закони змін і певні чіткі вияви" (Вернадский, 1991, с. 198). Далі науковець доводив, що 
людина стає найбільшою геологічною силою завдяки моральній культурі.

Сучасний підхід у формуванні моральної культури майбутнього вчителя початкових класів засобами ІКТ повинен грунтуватися й на засадах креативності, творчості. Творчість $\epsilon$ найхарактернішою ознакою особистості, вона завжди пов'язана 3 максимальним використанням інтелектуальної, почуттєвої і вольової сфер вчителя. "Процес творчості, - наголошував В. Сухомлинський, - характерний тим, що творець самою працею своєю і їі наслідками справляє величезний вплив на тих, хто поряд 3 ним. Одухотворення й натхнення однієї особистості породжує одухотворення й натхнення в душах інших людей. Творчість - це незримі ниточки, які об'єднують серця" (Сухомлинський, 1976, с. 507). 3 іншого боку, творчість $є$ необхідним елементом не лише продуктивного навчання, розвитку учнів, а й власного розвитку вчителя, умовою його самореалізації.

Холістичний підхід щодо підготовки майбутнього вчителя початкових класів, формування його моральної культури вимагає послідовної гуманізації усього навчальновиховного процесу. Мова йде не про якісь фрагментарні речі гуманізації, має гуманізуватися навчально-виховний процес як цілісна система, яка максимально відповідала б очікуванням особистості майбутнього педагога, уможливлювала б якісне, повноцінне набуття ним моральної культури. Цьому повинні сприяти передусім культурно-освітне середовище закладу, інформаційно-технічне забезпечення, готовність і реальне бажання професорсько-викладацького складу до утвердження гуманних, толерантних взаємин у системі "викладач - студент; студент - викладач", а також уся діяльність адміністрації. Натомість зауважимо, що в педагогічних університетах у цьому сенсі існує певна проблема. Маємо на увазі надмірну особистісну, методичну опіку студентів. У європейських університетах вважається анахронізмом організація навчальновиховного процесу за принципом патерналізму, там основний акцент робиться на самостійному навчанні i самоконтролі, чому допомагає сувора селекція протягом усіх років навчання, але особливо на першому курсі, і це також сприймається як важливий та необхідний критерій досягнення якості освіти, іії гуманізації. Отож маємо на увазі не стільки збереження контингенту, скільки домінування імперативу підтримання високої репутації навчального закладу.

3 погляду ідеї людино- й дитиноцентризму, збереження "інтелектуальної енергії", духовної, моральної культури держави сьогодні взагалі виникає багато різних проблем, пов'язаних із сферою духовно-культурного, гуманітарного пізнання i його реалізації у процесі підготовки майбутнього вчителя початкових класів. Особливо поглибленого вивчення потребують питання філософсько-світоглядного, морально-культурного освоєння світу i тих процесів, які безпосередньо відбуваються в Україні та системі їі освіти. Як слушно зазначає академік I. Прокопенко: "Неувага до світоглядної культури учнівської та студентської молоді призводить до захоплення частиною молоді езотеричними вченнями, нетрадиційними культами і релігіями, що паралізують волю і розум молоді, стоять на перешкоді їі професійної і особистісної самореалізації. Прояви політичного і правового нігілізму пов'язані і з низьким рівнем світоглядної культури. Гуманітаризація освіти покликана сприяти світоглядному вихованню, але ій слід надати більш практичну спрямованість" (Прокопенко, 2008, с. 43). У розв'язанні даної проблеми, на наше переконання, має спрацьовувати методологія плюралістичного аналізу. Моральна культура майбутнього вчителя початкових класів теоретично і практично повинна тісно пов'язуватися із свободою дії, свободою вибору, вільного викладу думки, того, що називається "діалог культур".

На нашу думку, з метою якісного формування моральної культури вчителя початкової школи слід максимально використовувати християнські підходи і цінності. Аналіз ситуації у цій царині засвідчує, що тут за попередні роки "войовничого атеїзму" накопичилося надто багато проблем. Натомість і сьогодні ця традиція "радянщини" усе ще діє. Наприклад, державні діячі, можновладці від освіти і науки часто-густо заперечують необхідність підготовки вчителів початкових класів на християнських засадах, це ж стосується розробки й упровадження в навчальний процес підручників, навчально-методичних посібників $з$ предметів "Християнська етика", "Родинне виховання" тощо. Надто суб'єктивні прочитання наукових і навчальних текстів 3 названих предметів деякими бюрократами від освіти лише заважають формуванню моральної культури студента, зневажають доробки відомих учених, їх зусилля на покращення ситуації у царині духовності.

Висновки та перспективи подальших досліджень. Проведений теоретичний аналіз значного масиву першоджерел, власна педагогічна діяльність дають можливість стверджувати, що сучасне наукове обгрунтування процесу формування моральної культури в майбутніх учителів початкових класів засобами інформаційно-комунікаційних технологій має свої здобутки і творчі знахідки, а також проблеми, які потребують практичного розв'язання.

Моральна культура майбутнього вчителя початкових класів - це інтегративний духовно-соціологічний, психолого-педагогічний феномен, формування якого потребує використання відповідних методологічних засад, законів і закономірностей, принципів застосування інноваційних технологій, однією 3 яких є інформаційно-комунікаційна.

Найбільш ефективним сучасним підходом у системі формування моральної культури майбутнього вчителя початкових класів вважаємо холістичний, який дозволяє навчати і виховувати цілісну, усебічно розвинену особистість педагога $з$ її гуманістичним науковим світоглядом, високим рівнем знань, умінь і навичок.

До основних напрямів подальших наукових пошуків відносимо: а) критичний аналіз і використання зарубіжного досвіду з метою удосконалення процесу формування моральної культури майбутнього вчителя початкових класів засобами IKT; б) наукове визначення критеріїв, показників сформованості моральної культури майбутнього вчителя початкових класів; в) створення структурно-функціональної моделі формування моральної культури майбутнього вчителя початкових класів засобами IКТ тощо. 


\section{СПИСОК ЛІТЕРАТУРИ}

Бех, І. Д. (2006). Виховання особистості: сходження до духовності. Київ : Либідь.

Бешок, Т. В. (2014). Педагогічні умови застосування медіаосвітніх технологій у професійній підготовці майбутніх учителів. (Дис. .. канд. пед. наук). Ін-т професійно-технічної освіти НАПН України, Київ.

Будник, О. Б. (2014). Професійна підготовка майбутніх учителів початкової школи до соціально-педагогічної діяльності: теорія і практика. Дніпропетровськ : Середняк Т. К.

Васянович, Г. П., Онищенко, В. Д. (2012). Ноологія особистості. Львів : Сполом.

Вернадский, В. И. (1991). Научная мысль как планетарное явление. Москва : Наука.

Гончаренко, С. У. (2008). Фундаменталізація професійної освіти як дидактичний принцип. Теорія $i$ практика управління сочіальними системами: філософія, психологія, педагогіка, соиіологія, 2, 87-91.

Гуревич, Р. С. (2008). Формування готовності до професійної діяльності майбутніх учителів у галузі інформаційно-комунікаційних технологій. Теорія і практика управління сочіальними системами: філософія, психологія, педагогіка, сочіологія, 2, 92-98.

Каплінський, В. В. (2017). Методика викладання у вищій школі. Київ :KHT.

Кремень, В. Г. (2008). Освітня діяльність і інтелект: проблеми формування національної інтелігенції. Теорія і практика управління соиіальними системами: філософія, психологія, педагогіка, соціологія, 2, 3-11.

Огієнко, I. (1992). Українська культура. Коротка історія культурного життя українського народу. Київ : Довіра.

Прокопенко, І. Ф. (2008). Професійне самовизначення молодої генерації української інтелігенції: проблеми і чинники впливу. Теорія i практика управління сочіальними системами: філософія, психологія, педагогіка, соиіологія, 2 , 40-44.

Сухомлинський, В. О. (1976). Методика виховання колективу. Вибрані твори (Т. 1). Київ : Рад. школа.

\section{REFERENCES}

Bekh, I. D. (2006). Vykhovannia osobystosti: skhodzhennia do dukhovnosti. Kyiv: Lybid. (Education of the personality: an approach to spirituality: a scientific edition).

Beshok, T. V. (2014)/ Pedahohichni umovy zastosuvannia mediaosvitnikh tekhnolohii u profesiinii pidhotovtsi maibutnikh uchyteliv. (Dys. ... kand. ped.. nauk. In-t profesiino-tekhnichnoi osvity NAPN Ukrainy, Kyiv. (Pedagogical conditions of application of mediaeducational technologies in professional training of future teachers).

Budnyk, O. B. (2014). Profesiina pidhotovka maibutnikh uchyteliv pochatkovoi shkoly do sotsialnopedahohichnoi diialnosti: teoriia $\mathrm{i}$ praktyka. Dnipropetrovsk : Seredniak T. K. (Professional preparation of future elementary school teachers for social and pedagogical activity: theory and practice).

Vasianovych, H. P., Onyshchenko V. D. (2012). Noolohiia osobystosti. Navchalnyi posibnyk. Lviv : Spolom. (Noology of personality. Textbook.) Vernadskyi, V. Y. (1991). Nauchnaia mysl kak planetarnoe yavlenye. Moskva : Nauka. (Scientific thought as a planetary phenomenon).

Honcharenko, S. U. (2008). Fundamentalizatsiia profesiinoi osvity yak dydaktychnyi pryntsyp Teoriia $i$ praktyka upravlinnia sotsialnymy systemamy: filosofiia, psykholohiia, pedahohika, sotsiolohiia, 2, 87-91. (Fundamentalization of vocational education as a didactic principle).

Hurevych, R. S. (2008). Formuvannia hotovnosti do profesiinoi diialnosti maibutnikh uchyteliv u haluzi informatsiinokomunikatsiinykh tekhnolohii. Teoriia i praktyka upravlinnia sotsialnymy systemamy: filosofiia, psykholohiia, pedahohika, sotsiolohiia, 2, 92-98. (Formation of readiness for professional activity of future teachers in the field of information and communication technologies).

Kaplinskyi, V. V. (2017). Metodyka vykladannia u vyshchii shkoli. Kyiv : KNT. (Teaching methods in the higher school: Textbook).

Kremen, V. H. (2008). Osvitnia diialnist i intelekt: problemy formuvannia natsionalnoi intelihentsii. Teoriia i praktyka upravlinnia sotsialnymy systemamy: filosofiia, psykholohiia, pedahohika, sotsiolohiia, 2, 3-11. (Educational activity and intelligence: problems of formation of national intelligentsia).

Ohiienko, I. (1992). Ukrainska kultura. Korotka istoriia kulturnoho zhyttia ukrainskoho narodu. Kyiv : Dovira. (A brief history of the cultural life of the Ukrainian people).

Prokopenko, I. F. (2008), Profesiine samovyznachennia molodoi heneratsii ukrainskoi intelihentsii: problemy i chynnyky vplyvu. Teoriia i praktyka upravlinnia sotsialnymy systemamy: filosofiia, psykholohiia, pedahohika, sotsiolohiia, 2, 40-44. (Professional self-determination of the young generation of the ukrainian intelligentsia: problems and factors of influence).

Sukhomlynskyi, V. O. (1976). Metodyka vykhovannia kolektyvu. Vybrani tvory. T. 1. Kyiv : Rad. shkola. (Methods of collective upbringing).

Стаття надійшла 1.04.2020 p. 